\title{
KONFLIK DAN STRES KERJA DALAM ORGANISASI
}

\author{
Ni Kadek Suryani ${ }^{(1)}$ \\ Gede Agus Dian Maha Yoga ${ }^{(2)}$ \\ ${ }^{(1)}$ Pascasarjana Universitas Mahasaraswati, Denpasar \\ ${ }^{(2)}$ Fakultas Ekonomi Universitas Hindu Indonesia, Denpasar \\ Email: suryani.staal@gmail.com
}

\begin{abstract}
Abstrak
Tingginya tuntutan pekerjaan, kompleknya alur kerja, dan semakin tingginya tujuan organisasi menuntut setiap karyawan harus bekerja dengan cepat, fokus dan maksimal. Tekanan kerja disini menjadi sisi yang terus di hadapi oleh para karyawan, dimana tekanan kerja yang tinggi akan dapat mengakibatkan mereka mengalami stres disamping memunculkan konflik diantara mereka. Hal ini menjadi masalah serius saat ini yang dihadapai organisasi dalam menghadapi persaingan global.

Stres jika tidak ditangani dengan segera akan dapat menimbulkan pengaruh yang merusak jasmani dan rohani disamping dapat berbahaya bagi kesehatan mereka. Demikian halnya dengan konflik, merupakan keadaan dimana tidak adanya keserasian antara berbagai hal pada seseorang dengan lingkungannya, termasuk pekerjaan dan orang-orang disekitarnya. Oleh karenanya peran serta organisasi dan karyawan diperlukan dalam kaitannya manajemen penanganan stres dan konflik dalam organisasi
\end{abstract}

Kata kunci : konflik kerja, stres kerja, kinerja karyawan, kinerja organisasi

\section{PENDAHULUAN}

Tidak dapat dipungkiri, seiring perkembangan sebuah organisasi akan terjadi peningkatan pekerjaan dan membutuhkan dukungan kerja maksimal dari sumber daya manusia yang dimilikinya. Seiring peningkatan tersebut, banyak dijumpai karyawan yang tidak sanggup bertahan dalam tekanan pekerjaan dan tuntutan target yang diberikan. Dalam situasi seperti ini berbagai masalah dapat 
menimpa para individu tersebut atau para anggota organisasi yang salah satunya adalah masalah stress dan konflik kerja dalam organisasi.

\section{Stres Kerja}

Dalam sebuah perusahaan, semakin besar perkembangannya maka semakin tinggi pekerjaan yang ada didalamnya, kondisi ini menuntut semakin banyak karyawan yang dibutuhkan bekerja di dalamnya sehingga besar kemungkinan timbulnya permasalahan, terutama permasalahan manusia yang ada didalamnya. Kondisi ini menyebabkan semakin tinggi tuntutan pekerjaan semakin banyak tekanan yang menyertai karyawan dalam pekerjaannya dimana tekanan kerja tersebut dapat memicu berbagai hal termasuk didalamnya stres kerja bagi mereka.

Stres merupakan salah satu bidang perhatian utama saat ini dalam organisasi apapun dan dapat dianggap sebagai sebuah akibat desakan berbagai permasalahan yang dihadapi manusia yang ada di dalam organisasi. Sehingga stres dimanifestasikan ketika orang berhadapan dengan begitu banyak tekanan yang menyebabkan pola perilaku normal mereka menjadi terpengaruh. Dengan kata laini stres umumnya terjadi karena adanya kondisi ketegangan yang berpengaruh terhadap emosi, jalan pikiran dan kondisi fisik seseorang (Sondang P Siagian, 2011).

Rivai Veithzal (2004) menyebutkan stres kerja merupakan sesuatu kondisi ketegangan yang menciptakan adanya ketidakseimbangan fisik dan psikis yang mempengaruhi emosi, proses berpikir, dan kondisi seorang karyawan terhadap 
lingkungannya . Artinya stres terjadi akibat di picu oleh ketidaknyamanan diri oleh hal-hal di sekitarnya yang mempengaruhi kestabilan emosi mereka.

Terjadinya stres kerja dapat dipahami sebagai keadaan dimana seseorang menghadapi tugas atau pekerjaan yang tidak bisa atau belum bisa dijangkau oleh kemampuannya, contohnya apabila kemampuan seseorang baru sampai angka 5 (lima) tetapi menghadapi pekerjaan yang menuntut kemampuan dengan angka 9 (sembilan), maka sangat mungkin sekali orang itu akan terkena stres kerja (sasono Eko, 2004). Handoko (2008) menyebutkan bahwa stres kerja merupakan suatu kondisi ketegangan yang mempengaruhi proses berpikir, emosi, dan kondisi psikis seseorang, hasilnya stres yang terlalu berlebihan dapat mengancam kemampuan seseorang untuk menghadapi lingkungan dan pada akhirnya akan mengganggu pelaksanaan tugas-tugasnya.

Sehingga dari uraian tersebut dapat dikatakan bahwa stres kerja adalah ketidaknyamanan perasaan yang dialami seseorang yang menekan atau merasa tertekan dalam menghadapi lingkungan dan pekerjaan mereka. Stres yang muncul yang berhubungan dengan pekerjaan dapat berupa tanggapan yang dimiliki seseorang ketika tuntutan dan tekanan kerja yang dihadapi tidak sesuai dengan pengetahuan dan kemampuan mereka. Dalam hal ini nampak semakin banyaknya tuntutan dan tekanan kerja yang tidak sesuai dengan pengetahuan dan kemampuan karyawan maka semakin tinggi kemungkinan mereka mengalami stres kerja, begitu juga sebaliknya.

Seseorang yang mengalami stres cenderung tidak sehat, tidak termotivasi, serta kurang produktif dan kurang nyaman di tempat kerja, ini akan berdampak 
pada kurang berhasilnya mereka dalam mendukung kegiatan organanisasi. Disamping itu akibat stres dapat pula menyebabkan orang-orang menjadi nerveous dan merasakan kekhawatiran kronis. Mereka sering menjadi marahmarah, agresif, tidak dapat rileks, atau memperlihatkan sikap yang tidak kooperatif. Agar stres dapat dikelola dan di minimalkan, hendaknya karyawan secara individu dan manajemen perlu mengetahui faktor-faktor penyebab stres kerja dalam organisasi.

Menurut Stavroula Leka et al., (2003), dalam kontek pekerjaan sehari-hari, karyawan yang mengalami stres banyak disebabkan oleh faktor-faktor antara lain:

a. Jenis pekerjaan seperti tugas yang monoton, kurang tantangan, kurangnya variasi, tugas yang tidak menyenangkan

b. Beban kerja dan kecepatan kerja seperti terlalu sedikit waktu untuk dilakukan, pekerjaan di bawah tekanan waktu, jadwal kerja yang ketat dan tidak fleksibel, jam kerja tak terduga, jadwal shift yang dirancang buruk

c. Partisipasi dan control seperti kurangnya partisipasi dalam pengambilan keputusan, kurangnya kontrol (misalnya, atas metode kerja, bekerja dengan kecepatan tinggi).

d. Pengembangan Karier, status dan kompensasi seperti keamanan pekerjaan, kurangnya prospek promosi, skema pembayaran yanglemah, besaran pembayaran yang minim, sistem evaluasi kinerja yang tidak jelas, Hubungan interpersonal,

e. Hubungan kerja seperti hubungan yang buruk dengan rekan kerja, penindasan, pelecehan, dan kekerasan, tidak ada prosedur kerja 
f. Budaya Organisasi seperti komunikasi yang buruk, system kepemimpinan yang buruk, kurangnya kejelasan tentang tujuan organisasi,

g. Masalah pribadi seperti konflik tuntutan pekerjaan dan rumah, kurangnya dukungan di tempat kerja, kurangnya dukungan untuk masalah pekerjaan di rumah.

Disamping itu kebijakan dan strategi administratif, prosedur, struktur dan desain organisasi, proses organisasi, dan kondisi lingkungan kerja juga ditemukan sebagai penyebab stres kerja karyawan disamping hal-hal terkait dengan pekerjaan utama mereka termasuk ambiguitas peran, kelebihan beban, ketidakamanan pekerjaan, konflik keluarga-kerja, ketidakpastian lingkungan dan kendala situasional pekerjaan. Banyak penelitian telah dilakukan dan membuktikan bahwa seluruh penyebab stres tersebut berhubungan negatif terhadap kinerja pekerjaan dan kinerja organisasi (Luthan Fred, 2011). Artinya semakin meningkat tingkat stres yang dialami karyawan maka semakin menurun kinerja mereka yang akhirnya mempengaruhi kinerja organisasi mereka secara menyeluruh.

Pada penelitian yang dilakukan Iskandar Muda et al., (2004) di bank syariah di Indonesia ditemukan stres kerja merupakan faktor yang berpengaruh signifikan terhadap kinerja yang dihasilkan karyawan. Didapati stres kerja memiliki pengaruh negatif atau tinggi tingkat stess yang dialami karyawan semakin menurun kinerja yang dihasilkan begitu juga sebaliknya, sehingga disarankan penting bagi manajemen untuk selalu memperhatikan dan memperbaiki strategi pada penanganan stres dalam organisasi. 


\section{Strategi Menangani Stres Kerja}

Stres kerja adalah perasaan yang menekan atau merasa tertekan yang dialami karyawan dalam menghadapi pekerjaannya. Stres kerja karyawan berdampak pada produktifitas dan semangat kerja mereka, oleh karenanya peran serta organisasi dalam hal ini manajemen dalam penanganannya perlu mendapatka perhatian serius.Strategi organisasi dalam mengelola stres kerja perlu dirancang oleh manajemen untuk menghilangkan atau mengontrol stres serta untuk mencegah atau mengurangi stres yang dirasakan karyawan.

Menurut Jeremy Stranks (2005) pembuatan strategi organisasi akan mampu membantu dalam penanggulangan stres di tempat kerja. Strategi organisasi yang dapat diterapka dapat berupa:

a. Penetapan prosedur kesehatan dan kesejahteraan karyawan. Ini termasuk berbagai bentuk pengawasan kesehatan, kegiatan promosi kesehatan, konseling tentang isu-isu yang berhubungan dengan kesehatan dan penyediaan fasilitas kesejahteraan yang memadai dll. Standar-standar ini mendorong para manajer, karyawan, karyawan dan perwakilan mereka untuk bekerja sama mengidentifikasi potensi penyebab stres di tempat kerja dan kemudian mengambil tindakan untuk memperbaiki situasi.

b. Gaya manajemen: disini menyangkut peduli lingkungan sangat penting, penerapan sistem komunikasi yang baik dan keterbukaan pada semua masalah yang di hadapi karyawan.

c. Manajemen perubahan. Manajemen harus menyadari bahwa perubahan yang akan datang, dalam bentuk apa pun, adalah salah satu penyebab stres yang 
paling signifikan di tempat kerja. Hal ini umumnya terkait dengan ketidakpastian pekerjaan, ketidakamanan, ancaman pemutusan hubungan kerja, hilangnya prospek promosi dan sebagainya. Untuk menghilangkan efek perubahan yang berpotensi menimbulkan stres, tingkat komunikasi yang tinggi dalam hal apa yang terjadi harus dijaga dan setiap perubahan tersebut harus dikelola dengan baik pada tahap demi tahap.

d. Kegiatan pelatihan: Kegiatan pelatihan karyawan harus mempertimbangkan potensi stres dalam aktivitas kerja tertentu. Orang harus dilatih untuk mengenali unsur-unsur stres dalam pekerjaan mereka dan strategi yang tersedia untuk mengatasi stres ini. Selain itu, desain pekerjaan dan organisasi kerja harus didasarkan pada prinsip-prinsip kopetensi dan keahlian mereka.

Strategi menghadapi stres juga dapat dilakukan dari sisi individu itu sendiri seperti misalnya melalui menjauhkan dari penyebab stres, mengolah pemikiran dengan mengganti persepsi tentang stres, menghilangkan penyebab stres, mengontrol peningkatan stres dan meminta dukungan sosial dari orangorang sekitar. Disamping itu juga dapat dilakukan melalui disiplin diri dengan membuat rencana kerja yang teratur, target kerja atau program-program kerja yang dapat dijangkau.

Mada Sutapa (2007) menyebutkan stres dalam organisasi tidak selamanya membahayakan kehidupan organisasi, sepanjang stres yang muncul hanya akan berada pada tingkat yang rendah atau moderat. Alasannya adalah karena stres pada tingkat tertentu memang diperlukan karena dapat bersifat fungsional yang berperan sebagai pendorong peningkatan kinerja anggota organisasi. Tetapi stres 
harus segera dikurangi atau dihentikan apabila gejala yang timbul akan berakibat pada stres yang berkepanjangan atau berat yang akan bersifat disfungsional dan menurunkan kinerja yang pada akhirnya akan menimbulkan stres pada tataran organisasional yang akan membahayakan kelangsungan hidup organisasi. Manajemen harus mengambil langkah-langkah untuk menghilangkan atau mengurangi jumlah dan intensitas stres dalam rangka peningkatan efektivitas organisasi.

\section{Konflik Kerja}

Setiap manusia akan selalu memiliki persepsi ketidaksetaraan atau perbedaan sudut pandang terhadap sesuatu, sehingga perbedaan ini dapat menimbulkan konflik (Suryani, et al, 2014). Konflik kerja dapat timbul baik pada organisasi kecilmaupun besar. Konflik kerja biasanya terjadi sebagai hasil adanya masalah - masalah yang ada dalam lingkungan pekerjaan seperti masalaha komunikasi, hubungan pribadi, ataupun struktur organisasi.

Sedarmayanti (2000) memberikan difinisi konflik sebagai perjuangan antara kebutuhan, keinginan, gagasan, kepentingan ataupun pihak yang saling bertentangan, sebagai akibat dari adanya perbedaan sasaran (goals); nilai (values); pikiran (cognition); perasaan (affect); dan perilaku (behavior). Disini konfilk yang terjadi dalam organisasi merupakan sebuah proses interaksi antar anggota yang ada di dalam organisasi yang lebih bersifat pertentangan karena suatu perbedaan atau ketidak sepakatan.

Sehingga dapat bahwa munculnya konflik dalam organisasi dikarenakan adanya ketidaksesuaian antara dua atau lebih anggota-anggota atau kelompok 
dalam organisasi yang timbul karena adanya kenyataan pertentangan atau ketidaksamaan tujuan, tuntutan, keinginan, atau kebutuhan diantara mereka. Sehingga dalam sebuah organisasi, konflik dapat terjadi karena adanya tujuan yang tidak sesuai, gangguan pada lingkungan kerja, ketidaksamaan persepsi dan perbedaan pandangan atas tujuan bersama. Jadi intinya bahwa konflik muncul dari adanya ketidaksetujuan atas tujuan yang ingin dicapai atau metode yang digunakan untuk mencapai tujuan tersebut.

Pada intinya konflik kerja merupakan sebuah interaksi akibat pertentangan yang terjadi antara dua atau lebih pihak dalam lingkungan pekerjaan akibat perbedaan antara apa yang diharapkan oleh seseorang dengan kenyataan yang dihadapi. Oleh karenanya agar konflik dapat dikelola dengan benar seharusnya orang-orang yang terlibat dalam organisasi mengetahui penyebab dari terjadinya konflik.

Menurut Sopiah (2008) dari beberapa penyebab konflik yang ada, tiga penyebab berikut dipandang sebagai penyebab dasar atas terjadinya konflik dalam organisasi yaitu :

a. Saling bergantungan. Saling bergantung dalam pekerjaan terjadi jika dua orang atau dua kelompok dalam organisasi saling membutuhkan satu sama lain guna menyelesaian tugas namun mereka tidak saling mendukung.

b. Perbedaan tujuan. Perbedaan tujuan yang ada diantara satu bagian dengan bagian yang lain, seperti unit produksi yang bertujuan semaksimal mungkin biaya produksi dan mengusahakan sesedikit mungkin kerusakan produk, sementara bagian penelitian dan pengembangan berurusan dengan 
pengembangan ide-ide baru untuk mengubah dan mengembangkan produk yang berhasil secara komersial. Hal ini dapat menjadi potensi munculnya konflik diantara mereka.

c. Perbedaan persepsi. Dalam menghadapi suatu masalah, jika terjadi perbedaan persepsi maka hal itu dapat menyebabkan munculnya konflik.

Lebih mengkhusus pada konflik kerja Angelina Muganza (2014), menjelaskan konflik di tempat kerja cenderung terjadi karena dua hal yaitu konflik antar individu dan konflik antar kelompok. Konflik antar individu terjadi yang melibatkan rekan kerja, karyawan, dan manajer mereka. Konflik ini dapat terjadi dalam arah vertikal ataupun horisontal. Misalnya karyawan konflik dengan rekan kerja, atasan yang konflik dengan bawahan atau sebaliknya, Sementara konflik yang terjadi diantara kelompok-kelompok yang melibatkan tim atau kelompok besar karyawan dan manajemen dapat terjadi dalam bentuk persaingan antar tim; atau mungkin terlihat oleh kurangnya kepercayaan dan kerja sama antara kelompok besar karyawan dan manajemen. Sehingga disini perlu nya strategi dari para pengelola usaha atau manajer untuk mencari jalan keluar atas konflik yang dihadapai karyawan mereka dan mencari prosedur pencegahannya.

\section{Strategi Mengelola Konflik}

Terkadang, konflik yang dihadapi tidak bisa dihindari sehingga setiap anggota organisasi penting untuk mengetahui cara menangani dan mengelola konflik yang terjadi. Sebuah penelitian yang dilakukan oleh College of Nurses of Ontario Toronto (2017) memberikan langkah pencegahan dan pengelolaan konflik dalam organisasi yang dapat dilaksanakan oleh manajemen yaitu: 
a. Manajemen mengimplementasikan kebijakan yang telah ditetapkan tanpa memberika toleransi atas tindakan yang menyalahi aturan tersebut

b. Memastikan bahwa kebijakan yang ditetapkan tidak mengandung diskriminasi

c. Memastikan bahwa manajer memberi contoh yang profesional dalam mencegah dan mengelola konflik;

d. Mendidik seluruh anggota organisasi dalam berkomunikasi khususnya pada setiap masalah yang terjadi dan menerapkan strategi untuk mengurangi stres di antara staf;

e. Membantu sesegera mungkin karyawan yang memiliki masalah, terutama pada waktu-waktu sibuk dan memastikan lingkungan kerja fisik yang nyaman dan aman

Disaat konflik sudah terjadi, maka manajemen hendaknya semakin peka untuk segera menangani dan mencarikan jalan keluar. Untuk penanganan awal, manajemen dapat melakukan langkah-langkah membantu mereka melalui menfasilitasi, menkonsiliasi, memediasi dan menegosiasi mereka yang sedang berselisih (Barrister, et al, 2014).

Perlu disadari bahwa konflik dalam organisasi tidak selalu berdampak negatif, namun ada kalanya konflik juga dapat pula berdampak positif yang dapat dipandang sebagai peluang untuk pertumbuhan organisasi dan bahkan penguatan hubungan antar tim kerja atau individu didalamnya. Beberapa jenis atau tingkatan konflik mungkin terbukti bermanfaat apabila digunakan sebagai sarana untuk mendorong kemajuan organisasi pada tahapan perubahan atau inovasi. Dengan 
demikian konflik bukanlah sesuatu yang harus dihindari, namun konflik merupakan sesuatu hal yang perlu untuk dikelola agar dapat memberikan kontribusinya bagi pencapaian tujuan organisasi

Disamping berdampak positif, juga perlu diketahui dampak negatif yang ditimbulkan akibat konflk yang terjadi diantaranya munculnya stres kerja yang dapat berupa hubungan yang tidak harmonis, produktivitas menurun, ketidakamanan pekerjaan, pemborosan waktu kerja dan sumber daya, menurunnya semangat kerja, hilangnya komitmen untuk bekerja, meningktnya pengunduran diri, cedera moral, ketidakhadiran yang tidak beralasan, dan efek hukum (Angelina Muganza, 2014,). Sehingga dapat disarikan bahwa peran konflik menjadi positif atau negatif adalah tergantung dari bagaimana kita mengelola dan menegosiasikan tantangan dan rintangan yang dihadapi, mempengaruhi, memperkuat, atau berdamai terhadap konflik yang dihadapi tersebut.

\section{KESIMPULAN}

Semakin berkembangnya sebuah perusahaan, maka semakin tinggi pula tuntutan kinerja atau standar target kinerja yang ditentukan oleh perusahaan, hal ini akan membawa karyawan untuk berusaha mencapai target kinerja yang telah ditetapkan oleh perusahaan. Karyawan akan memaksimalkan kerja mereka, beradaptasi dengan perubahan lingkungan yang terjadi, sehingga kondisi ini akan rentan terhadap timbulkan konflik kerja dan tekanan kerja yang dapat menimbukan stres terhadap karyawan mereka. Stres dan konflik tidak bisa dipisahkah, karena konflik yang berat dan berkepanjangan akan memicu timbulnya konflik dalam diri individu maupun antar indvidu dalam organisasi. 
Konflik dan stres yang tidak ditangani dengan baik akan dapat berdampak pada pada kinerja karyawan yang nantinya akan mempengaruhi kinerja organisasi secara keseluruhan.

Penelitian yang dilakukan Alice dan Wilco (2013) pada industi hotel di Cina telah membuktikan bahwa konflik dalam organisasi dan stress kerja mempengaruhi kinerja karyawan. Didapati bahwa konflik dan stres kerja memiliki pengaruh negatif terhadap kinerja karyawan artinya semakin tinggi karyawan mengalami konflik kerja dan semakin tingginya stress mereka rasakan maka kinerja mereka akan menurun signifikan, demikian pula sebaliknya. Dimana konflik dan stres yang dirasakan karyawan juga mempengaruhi produktifitas dan kenyamanan mereka dalam bekerja. Pada penelitian tersebut di sarankan kepada para manajer bahwa konflik tempat kerja tidak dapat dihindari terutama ketika konflik yang melibatkan penyelesaian tugas atau konflik atas interaksinya dengan tim kerja. Manajer atau pemimpin harus membantu tim mereka dalam mendiagnosis jenis konflik yang muncul dan mengajari anggota tim cara mengelola konflik-konflik tersebut.

Mengetahui penyebab atau sumber pemicu stres dan konflik kerja perlu segera dipelajari oleh para pimpinan perusahaan agar mereka dapat menyusun strategi didalam mengantisipasi dan mengelola kedua masalah tersebut dalam organisasinya. Organisasi yang professional tentu akan mencari jalan atas permasalahan yang terjadi tersebut agar karyawan mereka dapat bekerja maksimal dan berproduktifitas dalam pencapaian tujuan organisasi yang telah ditetapkan. 


\section{SARAN}

1. Untuk mengurangi terjadinya konflik dan stres yang dihadapi karyawan, perlu dilakukan kegiatan-kegiatan atau program yang bersifat kekeluargaan untuk mendekatkan hubungan diantara sesama karyawan.

2. Manajemen agar membuat prosedur tugas dan peran serta struktur organisasi yang jelas agar terjadi kejelasan kerja setiap karyawan, tidak terjadi over load ataupun tekanan yang berlebihan

3. Membuat skema imbalan, jenjang karir dan training juga perlu mendapat perhatian manajemen mengingat hal tersebut sensitif di dalam memotivasi kerja mereka

4. Membuat strategi yang melibatkan karyawan dapat menyebabkan karyawan memperoleh pekerjaan yang sesuai dengan kemampuannya dan mereka bekerja untuk tujuan yang mereka inginkan serta adanya hubungan interpersonal yang sehat serta perawatan terhadap kondisi fisik dan mental mereka.

\section{DAFTAR PUSTAKA}

Angelina Muganza, 2014, Causes and Impacts of Conflict at Workplace, Public Services Commission, Republic of Rwanda, hal : 1-113

Alice H. Y. Hon dan Wilco W. Chan, 2013, The Effects of Group Conflict and Work Stress on Employee Performance, Special Focus on Human Resources in China Cornell Hospitality Quarterly 54 (2), hal : $174-18$

Barrister Ebe Oi-Oio' Iyiola, O. O. dan Osibanto, A. O., 2014, Managing Workplace Conflicts in Business Environment: The Role of Alternative Dispute Resolution (ADR), European Journal of Business and Management is:

College of Nurses of Ontario, 2017, Conflict Prevention and Management, College of Nurses of Ontario, Toronto

Handoko, T Hani. 2008. Manjemen Personalia, Yogyakarta BPFE Yogyakarta

Iskandar Muda, Ahmad Rafiki dan Martua Rezeki Harahap, 2004, Factors Influencing Employees' Performance: A Study on the Islamic Banks in 
Indonesia, International Journal of Business and Social Science, Vol. 5 No. 2; February 2014, hal : $73-80$

Jeremy Stranks, 2005, Stress at Work Management and Prevention, Elsevier Butterworth-Heinemann, Oxford UK

Luthans, Fred.s-p. 2011, Organizational behavior : an evidence-based approach12th editions, Published by the McGraw-Hill Companies, Avenue of the Americas, New York

Mada Sutapa, 2007, Stres dan Konflik Dalam Organisasi, Jurnal Manajemen Pendidikan, No. 01/Th III/April/2007, hal : $71-77$

Ni Kadek Suryani, Wayan Gde Sarmawa, Made Wardana, 2014, Work Family Conflict, Job Stress and Job Performance (Case Study Spa Employee In Bali), European Journal of Business and Management (EJBM), Vol.6, No.32, 2014, pp : $189-195$

Rivai, Veithzal. 2004. Manajemen Sumber Daya Manusia Untuk Perusahaan: Dari Teori Ke Praktik. Jakarta, Raja Grafindo Persfada

Sasono, Eko. 2004. Mengelola Stres Kerja. Semarang, Universitas Pandanaran

Sedarmayanti, 2000, Restrukturisasi dan Pemberdayaan Organisasi untuk Menghadapi Dinamika Perubahan Lingkungan Ditinjau dari Beberapa Aspek Esensial dan Aktual, CV Mandar Maju, Bandung

Sondang P Siagian, 2011, Manajemen Sumber Daya Manusia, Jakarta, Bumi Aksara

Sopiah, 2008, Perilaku Organisasional, Yogyakarta Andi Offset

Stavroula Leka, Amanda Griffiths dan Tom Cox, 2003, Work Organization \& Stress, Systematic Problem Approaches for Employers, Managers and Trade Union Representative, Health Series No. 3, Institute of Work, Health \& Organization, University of Nottingham Science and Technology Park, University Boulevard United Kingdom, hal : 6-7 